\title{
PROFIL TECNOLOGICAL PEDAGOGICAL AND CONTENT KNOWLEDGE MAHASISWA CALON GURU BIOLOGI
}

\author{
Sumiyati Sa'adah*1 ${ }^{1}$, Rahayu Kariadinata ${ }^{2}$ \\ ${ }^{1}$ Pendidikan Biologi Fakultas Tarbiyah dan Keguruan UIN Sunan Gunung Djati Bandung, \\ Jalan Cimincrang Soekarno Hatta Bandung, Jawa Barat \\ ${ }^{2}$ Pendidikan matematika Fakultas Tarbiyah dan Keguruan UIN Sunan Gunung Djati Bandung, \\ Jalan Cimincrang Soekarno Hatta Bandung, Jawa Barat
}

sumiyatisaadah@uinsgd.ac.id

\begin{abstract}
Abstrak. Tujuan dari penelitian ini adalah untuk menginvestigasi Technological Pedagogical And Content Knowledge calon guru biologi Program Studi Pendidikan Biologi Fakultas Tarbiyah dan Keguruan UIN SGD Bandung yang telah mengikuti program pengenalan lapangan (PPL). Metode penelitian yang digunakan adalah deskriptif dengan pendekatan kuantitatif. Sedangkan metode pengambilan data yang dilakukan adalah dengan metode survey terhadap 82 responden. Instrumen yang digunakan berupa kuesioner tertutup yang setiap pernyataannya didasarkan pada setiap komponen TPACK. Hasil penelitian menunjukkan bahwa Technological Pedagogical And Content Knowladge (TPACK) calon guru biologi Program Studi Pendidikan Biologi Fakultas Tarbiyah dan Kegurun UIN SGD Bandung berada dalam kategori baik dengan nilai rata-rata 3.6. Hal ini menunjukkan bahwa calon guru biologi telah memahami aspek-aspek yang terkait dengan technological pedagogical and content knowladge dalam proses pembelajaran.
\end{abstract}

Kata Kunci : Technological Pedagogical And Content Knowledge - calon guru biologi

Abstrack. The purpose of this study was to investigate Technological Pedagogical and Content Knowledge of pre-service biology teachers of Biology Education Department, Faculty Tarbiya and teacher training UIN SGD Bandung who had participated in PPL. The research method used is descriptive with a quantitative approach, while the method of data collection was carried out by survey method to 82 respondents. The instrument used is a questionnaire which each statement is based on each TPACK component. The results showed that Technological Pedagogical and Content Knowledge (TPACK) pre-service biology teachers of the Biology Education department, Faculty Tarbiya and teacher training UIN $S G D$ Bandung were in a good category $(M=3.6)$. Its mean that pre-service biology teachers have understood aspects related to technological pedagogical and content knowledge in the learning process.

Key word: Technological Pedagogical And Content Knowledge - pre-service biology teacher 


\section{PENDAHULUAN}

Salah satu penentu keberhasilan pendidikan adalah guru. Untuk itu mempersiapkan guru yang professional seharusnya dilakukan sejak awal, yaitu ketika mereka masih menjadi mahasiswa calon guru. Mahasiswa calon guru harus dibekalkan bagaimana metode mengajar, bagaimana menggunakan teknologi informasi dan komputer (TIK), memperkuat penguasaan tentang konten keilmuan dan mempelajari bagaimana siswa berpikir dan belajar (Alayar et al, 2012). Hal ini sejalan dengan apa yang dikemukakan oleh National Science Teacher Association (NSTA, 2012) bahwa standar untuk mempersiapkan guru sains (termasuk guru biologi) meliputi tiga tingkatan yaitu tingkatan preservice (calon guru), guru pemula (induction), dan guru profesional. Dengan kata lain, untuk meningkatkan kualitas pendidikan, termasuk kualitas pembelajaran biologi di sekolah, bukan hanya guru yang harus ditingkatkan keprofesionalannya, tetapi juga harus dimulai dari upaya untuk meningkatkan kualitas persiapan calon guru di LPTK.

Calon guru biologi, sudah seharusnya memiliki pengetahuan dan kemampuan tentang sains, belajar sains, dan mengajar sains (Nasional Research Council, 1996). Untuk memahami proses yang terjadi dalam suatu kegiatan pembelajaran dan memahami bagaimana pengaruh pengetahuan guru dalam suatu kegiatan pembelajaran Shulman (1986) mengusulkan suatu kerangka kerja (framework) pengetahuan guru yang dikenal dengan istilah Pedagogical Content Knowledge atau PCK. Menurut Shulman (1986, 1987), PCK merupakan gabungan bagian (interseksi) antara pengetahuan akan muatan materi subjek (content knowledge/CK) dengan pengetahuan tentang pedagogi (pedagogical knowledge/PK). PCK adalah gagasan yang muncul dari keyakinan bahwa mengajar membutuhkan lebih dari sekedar pemberian pengetahuan tentang materi atau muatan subjek kepada siswa dan siswa belajar tidak hanya sekedar menyerap informasi tapi bagaimana implementasinya. PCK adalah pengetahuan guru yang berkembang terus menerus melalui pengalaman tentang bagaimana mengajar konten tertentu dengan cara khusus agar pemahaman siswa dapat tercapai (Loughran et al, 2012).

Berdasarkan gagasan Shulman tentang PCK, Mishra \& Koehler (2006) telah menambahkan teknologi ke dalam PCK, dengan istilah TPACK (tecnological pedagogical and content knowledge). Menurut Mishra \& Koehler (2006), TPACK adalah kerangka kerja yang mencoba memahami hubungan antara pengetahuan tentang pengajaran (pedagogical knowledge), materi pelajaran (content knowledge), dan penggunaan teknologi (tecnological knowledge). Dalam TPACK, pengetahuan guru untuk mengintegrasikan teknologi dalam pembelajaran membuat pembelajaran mejadi efektif dan efisien. Integrasi teknologi dianggap sebagai komponen pengajaran yang terkait erat dan termasuk juga dalam PCK (Oyanagi dan Satake, 2016).

Perkembangan teknologi yang cepat pada abad 21 ini menjadikan tantangan bagi dunia pendidikan untuk mengembangkan dan menemukan alat yang menambah efisiensi dan nilai bagi proses pembelajaran.Teknologi memiliki pengaruh yang kuat di sekolah sebagai alat yang dapat mengubah cara subjek diajarkan dalam proses pembelajaran, dan pengajaran yang baik mengharuskan bagi guru dan siswa untuk menggunakan teknologi dalam mengumpulkan, mengatur, dan mengevaluasi informasi untuk memecahkan masalah (Srisaswadi, 2012). Mengintegrasikan ICT (TIK) ke dalam 
pengajaran dan pembelajaran di kelas terus menjadi tugas yang menantang bagi banyak guru. Guru merasa tidak siap untuk penggunaan TIK secara spesifik subjek dan kurang memiliki kerangka teoritis yang kuat (Chai et al, 2013). Terkait hal tersebut

\section{METODE PENELITIAN}

Metode penelitian yang dilakukan adalah penelitian deskriptif dengan pendekatan kuantitatif. Penelitian deskriptif adalah penelitian yang mendeskripsikan suatu kondisi, peristiwa, gejala, kejadian yang terjadi sekarang yang digambarkan oleh peneliti sebagaimana adanya (Neville, 2005). Pendekatan kuantitatif digunakan untuk mengukur komponen yang hendak diteliti yang digambarkan dalam bentuk angka-angka. Sedangkan metode pengambilan data yang dilakukan dalam penelitan ini adalah dengan metode survey. Survey dilakukan kepada mahasiswa calon guru biologi Program Studi Pendidikan Biologi Fakultas Tarbiyah dan Keguruan UIN SGD Bandung yang telah mengikuti program pengenalan lapangan (semester 8) sebanyak 82 mahasiswa.

\section{HASIL DAN PEMBAHASAN}

Hasil analisis terhadap data kuesioner TPACK mahasiswa calon guru biologi, rekapitulasinya disajikan pada Tabel 1 .

Tabel 1. Rekapitulasi hasil analisis angket pada setiap aspek TPACK

\begin{tabular}{|l|c|c|c|}
\hline \multicolumn{1}{|c|}{ ASPEK TPACK } & M & SD & Kriteria \\
\hline $\begin{array}{l}\text { Tecnological } \\
\text { Knowledge (TK) }\end{array}$ & $\mathbf{3 . 8 7}$ & $\begin{array}{c}0.4 \\
2\end{array}$ & Baik \\
\hline $\begin{array}{l}\text { Content Knowledge } \\
\text { CK) }\end{array}$ & $\mathbf{3 . 6 2}$ & $\begin{array}{c}0.2 \\
2\end{array}$ & Baik \\
\hline $\begin{array}{l}\text { Pedagogical } \\
\text { Knowledge }(P K)\end{array}$ & $\mathbf{3 . 7 3}$ & $\begin{array}{c}0.1 \\
4\end{array}$ & Baik \\
\hline $\begin{array}{l}\text { Technological } \\
\text { Content Knowledge }\end{array}$ & $\mathbf{3 . 7 0}$ & $\begin{array}{c}0.3 \\
7\end{array}$ & Baik \\
\hline
\end{tabular}

TPACK dianggap sebagai framework yang dapat memberikan arah baru bagi guru untuk memecahkan masalah tentang bagaimana mengintegrasikan TIK ke dalam kegiatan pembelajaran di ruang kelas (Hewitt, 2008).

Instrumen yang digunakan dalam penelitian ini adalah kuesioner tertutup yang berisi pernyataan yang harus diisi oleh guru tentang kesetujuan atau ketidaksetujuan mereka terhadap pernyataan-pernyataan yang diberikan dalam angket (skala likert). Pernyataan-pernyataan yang dibuat disesuaikan dengan aspek TPACK (diadaptasi Suryawati dkk, 2014; Tian dkk. 2012; Chai, Koh, Tsai, \& Tan, 2011; Schmidt et al, 2009) yang meliputi tentang Tecnological Knowladge (TK), Content Knowladge (CK), Pedagogical Knowladge (PK), Technological Content Knowledge (TCK) Technological Content Knowledge (TCK) Pedagogical Content Knowledge (PCK), Technological Pedagogical Knowledge (TPK), dan Technological Pedagogical Content Knowledge (TPCK). Kuesioner TPACK yang dikembangkan terdiri atas 62 pernyataan yang harus diisi oleh responden.

\begin{tabular}{|l|c|c|c|}
\hline \multicolumn{1}{|c|}{ ASPEK TPACK } & M & SD & Kriteria \\
\hline (TCK) & & & \\
\hline $\begin{array}{l}\text { Pedagogical Content } \\
\text { Knowledge (PCK) }\end{array}$ & $\mathbf{3 . 6 5}$ & $\begin{array}{c}0.1 \\
5\end{array}$ & Baik \\
\hline $\begin{array}{l}\text { Technological } \\
\text { Pedagogical } \\
\text { Knowledge (TPK) }\end{array}$ & $\mathbf{3 . 3 7}$ & $\begin{array}{c}0.2 \\
7\end{array}$ & Cukup \\
\hline $\begin{array}{l}\text { Technological } \\
\text { Pedagogical Content } \\
\text { Knowledge (TPCK) }\end{array}$ & $\mathbf{3 . 5 2}$ & $\begin{array}{c}0.1 \\
2\end{array}$ & Baik \\
\hline Rata-rata & $\mathbf{3 . 6 4}$ & $\begin{array}{c}0.1 \\
6\end{array}$ & Baik \\
\hline
\end{tabular}

Data yang disajikan pada Tabel 1. menunjukkan bahwa rata-rata kemampuan TPACK mahasiswa calon guru biologi berada dalam kategori baik, dengan nilai tertinggi pada aspek Tecnological 
Knowladege (PK) atau pengetahuan tentang teknologi. Hal ini dapat dipahami karena responden yang mengisi angket merupakan generasi $\mathrm{Y} / \mathrm{Gen} \mathrm{Y}$ atau disebut juga generasi milenial. Generasi Y merupakan generasi yang lahir pada tahun 80an sampai akhir 90an (White \& Kiegaldie, 2011; Hunt \& Tuciarone, 2011). Salah satu ciri generasi Y adalah terbiasa dengan teknologi informasi dan komputer (TIK) atau pintar dan nyaman dalam menggunakan teknologi (Behrstock \& Cliford, 2009; White \& Kidalgi, 2011; Hunt \& Tuciarone, 2011). Mereka juga memiliki kualifikasi yang tinggi dalam pengetahuan digital, oleh karena itu mudah dan cepat bagi mereka dalam mempelajari dan menggunakan teknologi informasi dan komputer (TIK) (Andrea et all, 2016). Dengan demikian pengetahun mereka tentang teknologi menjadi sangat tinggi. Hal yang menarik yang diungkapkan dari Tabel 1 di atas bahwa sekalipun tecnological knowledge (pengetahuan teknologi) calon guru biologi pada kategori sangat baik, akan tetapi pada aspek technological pedagogigal knowledge berada pada kategori cukup $(\mathrm{M}=$
3.37). Hal ini dapat dimaknai bahwa kemapuan calon guru biologi dalam menginegrasikan teknologi dalam proses pembelajaran lebih rendah dibandingkan kemamampuan mereka dalam menguasai teknologi itu sendiri. Hal ini terkait dengan kelengkapan sarana teknologi pada saat mereka melakukan praktik mengajar pada kegiatan PLL, tidak semua sekolah memiliki sarana teknologi seperti LCD/proyektor yang dapat membantu mereka untuk mengajar. Untuk melihat setiap aspek TPACK, hasilnya dipaparkan berikut ini:

\section{Technological Knowledge}

Technological Knowledge mengacu kepada pengetahuan tentang berbagai teknologi dari mulai low-technology sampai teknologi digital yang bisa diintegrasikan dalam kurikulum dan pembelajaran serta mengacu kepada keterampilan dalam menggunakannya (Schimdt, 2009; Kohler et all, 2014; De Rossi \& Trevisan, 2018). Hasil analisis data angket pada aspek Technological Knowledge dapat dilihat pada Tabel 2 berikut ini.

Tabel 2. Hasil angket untuk aspek Technological Knowledge

\begin{tabular}{|c|l|c|c|c|}
\hline NO & \multicolumn{1}{|c|}{ PERNYATAAN } & M & SD & KATEGORI \\
\hline 1 & $\begin{array}{l}\text { Dapat dengan mudah mempelajari dan menggunakan } \\
\text { teknologi computer }\end{array}$ & 4.10 & 0.7 & Baik \\
\hline 2 & Mengikuti perkembangan teknologi komputer terbaru & 3.71 & 0.7 & Baik \\
\hline 3 & Mengetahui cara mengatasi masalah teknis pada computer & 3.10 & 0.8 & Cukup \\
\hline 4 & $\begin{array}{l}\text { Memiliki kemampuan teknis untuk menggunakan komputer } \\
\text { secara efektif }\end{array}$ & 3.29 & 0.9 & Cukup \\
\hline 5 & $\begin{array}{l}\text { Mengetahui tentang komponen dasar-dasar perangkat keras } \\
\text { (hardware) komputer (seperti Hard disk, RAM, CD-ROOM, } \\
\text { motherbord) dan fungsinya }\end{array}$ & 3.29 & 0.9 & Cukup \\
\hline 6 & $\begin{array}{l}\text { Mengetahui tentang komponen dasar perangkan lunak } \\
\text { (software) komputer (seperti window, media player) dan } \\
\text { fungsinya }\end{array}$ & 3.69 & 0.8 & Baik \\
\hline 7 & Dapat menggunakan printer & 4.24 & 0.7 & Sangat baik \\
\hline 8 & Dapat menggunakan scanner & 3.75 & 1 & Baik \\
\hline 9 & Dapat menggunakan proyektor & 4.09 & 0.9 & Baik \\
\hline 10 & Dapat menggunakan digital camera & 4.18 & 0.9 & Baik \\
\hline
\end{tabular}




\begin{tabular}{|c|c|c|c|c|}
\hline NO & PERNYATAAN & $\mathbf{M}$ & SD & KATEGORI \\
\hline 11 & $\begin{array}{l}\text { Dapat menyimpan data secara digital (upload, download, CD, } \\
\text { DVD, flash card) }\end{array}$ & 4.25 & 1 & Sangat baik \\
\hline 12 & $\begin{array}{l}\text { Mahir menggunakan program pengolahan kata (seperti MS- } \\
\text { Word) }\end{array}$ & 4.21 & 1.1 & Sangat baik \\
\hline 13 & $\begin{array}{l}\text { Mahir menggunakan program pengolahan angka (seperti } \\
\text { (MS-Excel) }\end{array}$ & 3.60 & 1.3 & Baik \\
\hline 14 & $\begin{array}{l}\text { Mahir menggunakan program untuk presentasi (seperti Ms- } \\
\text { power point) }\end{array}$ & 4.19 & 1.3 & Baik \\
\hline 15 & $\begin{array}{l}\text { Mahir menggunakan progam untuk mengedit gambar (seperti } \\
\text { Ms-Paint) }\end{array}$ & 3.53 & 1.5 & Baik \\
\hline 16 & $\begin{array}{l}\text { Dapat menggunakan internet sebagai media komunikasi } \\
\text { (seperti email, yahoo messenger) }\end{array}$ & 4.50 & 1.4 & Sangat baik \\
\hline 17 & Dapat membuat web & 3.37 & 1.8 & Cukup \\
\hline \multirow[t]{2}{*}{18} & $\begin{array}{l}\text { Dapat menggunakan media sosial (seperti facebook, twitter, } \\
\text { instagram) }\end{array}$ & 4.80 & 1.7 & Sangat baik \\
\hline & Rata-rata & 3.88 & 1.08 & Baik \\
\hline
\end{tabular}

Berdasarkan Data yang disajikan pada Tabel 2 di atas menunjukkan bahwa kemampuan Tekcnological Knowledge (PK) calon guru biologi berada dalam kategori baik dengan nilai rata-rata 3.88. Hal ini berarti bahwa kemampuan calon guru biologi di bidang teknologi baik pengetahuan maupun keterampilannya sudah baik. Dari Tabel 2 diketahui bahwa rerata tertinggi terdapat pada item dapat menggunakan media sosial $(\mathrm{M}=4.8$, sangat baik). Data ini sejalan sejalan dengan survey yang dilakukan oleh asosiasi penyelenggara jasa internet indonesia (APJII, 2016) yang mengungkapkan bahwa pengguna internet di Indonesia pada tahun 2016 sebanyak 132,7 juta jiwa $(50 \%$ dari seluruh populasi penduduk) dengan 22,3 juta penggunanya berusia antara $20-24$ tahun dan konten internet yang paling banyak diakses oleh pengguna internet adalah sosial media sebanyak 129, 2 juta jiwa (97.7\%).

\section{Content Knowledge (CK)}

Content Knowledge mengacu kepada pengetahuan materi subjek yang harus dikuasai saat mengajar (Kohler et all, 2014; Schmidt \& Mishra, 2009), yang dalam konteks penelitian ini adalah materi atau konten biologi. Pengetahuan tentang konten materi meliputi berbagai istilah, teori, ide, kerangka kerja (Shulman, 1986). Hasil analisis data angket pada aspek Content Knowledge disajikan pada Tabel 3 berikut ini.

Tabel 3. Hasil angket untuk aspek Content Knowledge

\begin{tabular}{|c|l|c|c|c|}
\hline NO & \multicolumn{1}{|c|}{ PERNYATAAN } & SKOR & SD & KATEGORI \\
\hline 1 & $\begin{array}{l}\text { Memiliki pengetahuan yang cukup tentang materi biologi yang } \\
\text { akan saya ajarkan }\end{array}$ & 3.85 & 0.63 & Baik \\
\hline 2 & Mengikuti perkembangan ilmu biologi & 3.73 & 0.68 & Baik \\
\hline 3 & $\begin{array}{l}\text { Memiliki berbagai cara dan strategi untuk mengembangkan } \\
\text { pemahaman tentang materi biologi }\end{array}$ & 3.81 & 0.68 & Baik \\
\hline 4 & Dapat berpikir seperti seorang ahli biologi pada saat mengajar & 3.32 & 0.66 & Cukup \\
\hline
\end{tabular}




\begin{tabular}{|c|l|c|c|c|}
\hline NO & \multicolumn{1}{|c|}{ PERNYATAAN } & SKOR & SD & KATEGORI \\
\hline 5 & $\begin{array}{l}\text { Menggunakan sumber-sumber atau referensi terbaru (seperti } \\
\text { buku dan jurnal) untuk menambah pengetahuan kebiologian }\end{array}$ & 3.71 & 0.67 & Baik \\
\hline 6 & Mengikuti seminar atau workshop yang terkait biologi & 3.29 & 0.79 & Cukup \\
\hline 7 & $\begin{array}{l}\text { Dapat merancang dan menerapkan eksperimen Biologi untuk } \\
\text { tujuan pembelajaran }\end{array}$ & 3.62 & 0.93 & Baik \\
\hline \multicolumn{2}{|c|}{ Rata-rata } & 3.62 & 0.72 & Baik \\
\hline
\end{tabular}

Data yang disajikan pada Tabel 3 menunjukan bahwa aspek content knowledge calon guru biologi berada pada kategori baik dengan nilai rerata 3.62. Pengetahuan tentang konten materi (content knowledge) penting untuk dikuasai oleh guru (Mishra dan Koehler, 2008). Jika seorang guru tidak memiliki pengetahuan yang baik tentang konten materi yang akan diajarkannya dapat menyebabkan miskonsepsi dan keliru dalan menunjukkan fakta-fakta (Koehler \& Mishra, 2009).

\section{Pedagogical Knowledge}

Pedagogical Knowledge mengacu kepada pengetahuan tentang bermacam strategi dan metode mengajar termasuk pengetahuan tentang pengelolaan kelas, asesmen pembelajaran, serta pengembangan rencana pembelajaran (Kohler et all, 2014; Schmidt \& Mishra, 2009). Hasil analisis data angket pada aspek Pedagogical Knowledge dapat dilihat pada Tabel 4 berikut ini.

Tabel 4. Hasil angket untuk aspek Pedagogical Knowledge

\begin{tabular}{|c|l|c|c|c|}
\hline NO & \multicolumn{1}{|c|}{ PERNYATAAN } & SKOR & SD & KATEGORI \\
\hline 1 & Dapat menerapkan strategi pembelajaran yang bervariasi & 3.66 & 0.8 & Baik \\
\hline 2 & Dapat mengelola dan menguasai kelas dengan baik & 3.60 & 0.71 & Baik \\
\hline 3 & $\begin{array}{l}\text { Dapat menggunakan berbagai metode dan teknik } \\
\text { penilaian }\end{array}$ & 3.47 & 0.63 & Baik \\
\hline 4 & Dapat menilai kinerja siswa di dalam kelas & 3.82 & 0.66 & Baik \\
\hline 5 & $\begin{array}{l}\text { Menyadari kemungkinan terjadinya miskonsepsi dan } \\
\text { kesulitan pada siswa }\end{array}$ & 3.89 & 0.64 & Baik \\
\hline 6 & $\begin{array}{l}\text { Dapat menyesuaikan gaya mengajar saya dengan } \\
\text { perbedaan kemampuan siswa }\end{array}$ & 3.65 & 0.82 & Baik \\
\hline 7 & $\begin{array}{l}\text { Dapat membantu siswa saya untuk memantau } \\
\text { pembelajaran mereka sendiri }\end{array}$ & 3.72 & 0.79 & Baik \\
\hline 8 & Dapat merencanakan kegiatan kelompok untuk siswa saya & 3.94 & 0.87 & Baik \\
\hline 9 & $\begin{array}{l}\text { Dapat membimbing siswa saya untuk berdiskusi secara } \\
\text { efektif selama kerja kelompok }\end{array}$ & 3.88 & 0.86 & Baik \\
\hline 10 & $\begin{array}{l}\text { Melakukan tindakan reflektif untuk peningkatan kualitas } \\
\text { pembelajaran }\end{array}$ & 3.71 & 0.94 & Baik \\
\hline \multicolumn{2}{|r|}{ Rata-rata } & 3.73 & 0.77 & Baik \\
\hline
\end{tabular}

Tabel 3 di atas menunjukkan aspek Pedagogical Knowledge mahasiswa calon guru biologi berada pada kategori baik dengan nilai rerata sebesar 3.73. Hal ini berarti bahwa calon guru biologi telah memahami dan mengimplementasikannya prinsip-prinsip pedagogi dari mulai merencanakan, melaksanakan, dan menilai dalam pembelajaran di kelas, terutama saat mereka melaksanakan praktek pengenalan 
lapangan (PPL). Pengetahuan pedagogi merupakan pengetahuan yang penting untuk dikuasai oleh guru. Sebagaimana yang disampaikan dalam undang-undang No 14 tahun 2005 tentang guru dan dosen bahwa salah satu kompetensi yang harus dilmiliki guru dan dosen adalah kompetensi pedagogi. Sekalipun responden yang mengisi kuesioner ini adalah calon guru biologi, akan tetapi karena mereka dipersiapkan akan menjadi guru, maka pengetahuan calon guru biologi terkait aspek pedagogi menjadi penting dikuasai oleh mereka.

\section{Technological Content Knowledge (TCK) \\ Technological Content Knowledge} (TCK) adalah pengetahuan tentang hubungan timbal balik antara teknologi dengan konten/materi (Kohler et all, 2014), yang dalam hal ini adalah dengan konten biologi. Hasil analisis data angket pada aspek Technological Content Knowledge disajikan pada Tabel 5 berikut ini.

Tabel 5. Hasil angket untuk aspek Technological Pedagogical Knowledge

\begin{tabular}{|c|l|c|c|c|}
\hline NO & \multicolumn{1}{|c|}{ PERNYATAAN } & SKOR & SD & KATEGORI \\
\hline 1 & $\begin{array}{l}\text { Menggunakan teknologi untuk membantu memahami materi } \\
\text { biologi }\end{array}$ & 4.01 & 0.8 & Baik \\
\hline 2 & $\begin{array}{l}\text { Mengetahui dan dapat menggunakan aplikasi-aplikasi } \\
\text { komputer terkait biologi (misalnya mengunduh video atau } \\
\text { swf materi biologi) }\end{array}$ & 4.06 & 0.76 & Baik \\
\hline 3 & $\begin{array}{l}\text { Dapat mengembangkan aktivitas belajar dan tugas siswa yang } \\
\text { melibatkan pengunaan teknologi }\end{array}$ & 3.59 & 0.75 & Baik \\
\hline 4 & $\begin{array}{l}\text { Dapat memilih dan menggunakan teknologi yang sesuai } \\
\text { dengan materi biologi yang akan diajarkan }\end{array}$ & 3.71 & 0.69 & Baik \\
\hline 5 & $\begin{array}{l}\text { Dapat membuat kegiatan belajar secara mandiri bagi siswa } \\
\text { melalui penggunaan TIK (teknologi informasi dan komputer) } \\
\text { seperti seperti membuat webquest, flip }\end{array}$ & 3.14 & 0.78 & Cukup \\
\hline & RATA-RATA & 3.70 & 0.76 & Baik \\
\hline
\end{tabular}

Tabel 5 di atas menunjukkan bahwa rerata aspek Technological content knowledge calon guru biologi adalah 3.7 dengan kategori baik. Hal ini dapat dimaknai bahwa calon guru biologi telah mengetahui dan menggunakan dengan baik teknologi dalam menyampaikan materi saat pembelajaran berlangsung. Sebagaimana yang diungkapkan oleh Abbitt (2014) bahwa TCK merupakan pengetahuan bagaiamana teknologi dapat mempengaruhi dan dapat digunakan dalam mengeksplorasi disiplin ilmu. Schmidt \& Mishra (2009) mengungkapkan dengan TCK seorang guru dapat mengubah cara siswa dalam memahai dan berlatih tentang konsep dalam suatu disiplin ilmu. Penggunaan teknologi dapat mempermudah siswa dalam memahami konten biologi.

Pedagogical Content Knowledge (PCK)

Pedagogical Content Knowledge (PCK) menurut Shulman (1986) adalah pemahaman tentang bagaimana topik atau masalah tertentu dalam suatu bidang ilmu diorganisasikan, direpresentasikan, dan disesuaikan dengan beragam minat dan kemampuan peserta didik, dan diimplementasikan dalam proses pembelajaran. Hasil analisis data angket pada aspek Pedagogical Content Knowledge dapat dilihat pada Tabel 6 berikut ini. 
Tabel 6. Hasil angket untuk aspek Pedagogical Content Knowledge

\begin{tabular}{|c|l|c|c|c|}
\hline NO & \multicolumn{1}{|c|}{ PERNYATAAN } & SKOR & SD & KATEGORI \\
\hline 1 & $\begin{array}{l}\text { Dapat membuat rencana pelajaran (RPP) dengan pemahaman } \\
\text { yang baik tentang topi-topik biologi }\end{array}$ & 3.93 & 0.71 & Baik \\
\hline 2 & $\begin{array}{l}\text { Dapat memilih pendekatan dan strategi pengajaran yang } \\
\text { efektif untuk membantu siswa dalam belajar dan berpikir } \\
\text { biologi }\end{array}$ & 3.7 & 0.71 & Baik \\
\hline 3 & $\begin{array}{l}\text { Dapat membuat materi biologi yang sulit menjadi mudah } \\
\text { unuk dipahami oleh siswa saya }\end{array}$ & 3.47 & 0.65 & Baik \\
\hline 4 & $\begin{array}{l}\text { Dapat mengembangkan evaluasi pembelajaran untuk } \\
\text { mengukur penguasaan siswa terhadap materi biologi yang } \\
\text { saya ajarkan }\end{array}$ & 3.52 & 0.61 & Baik \\
\hline 5 & $\begin{array}{l}\text { Dapat membantu siswa saya memahami materi biologi yang } \\
\text { saya ajarkan dengan berbagai strategi meskipun tanpa } \\
\text { menggunakan teknologi }\end{array}$ & 3.73 & 0.66 & Baik \\
\hline 6 & $\begin{array}{l}\text { Saya dapat mengajak siswa aktif berdiskusi tentang materi } \\
\text { biologi yang saya ajarkan tanpa bantuan teknologi apapun }\end{array}$ & 3.71 & 0.77 & Baik \\
\hline 7 & $\begin{array}{l}\text { Saya dapat membuat siswa aktif untuk memecahkan masalah } \\
\text { biologi tanpa menggunakan teknologi }\end{array}$ & 3.60 & 0.83 & Baik \\
\hline 8 & $\begin{array}{l}\text { Saya dapat membantu mengubah proses berpikir siswa agar } \\
\text { bisa menguasai topik yang sulit mengenai materi biologi } \\
\text { tanpa menggunakan teknologi }\end{array}$ & 3.50 & 0.87 & Baik \\
\hline & RATA-RATA & 3.64 & 0.73 & Baik \\
\hline
\end{tabular}

Berdasarkan data yang disajikan pada Tabel 6 di atas terungkap bahwa nilai rararata aspek Pedagogical Content Knowledge calon guru biologi berada dalam ketegori baik $(M=3.64)$. Hal ini berarti bahwa calon guru biologi prodi pendidikan biologi UIN SGD bandung telah mampu mengabungkan antara pengetahuan mereka tentang pedagogi dan konten/materi biologi dalam pembelajaran di kelas. Mereka mengetahui cara memilih pendekatan/metode/model untuk menyampaikan konten/materi biologi yang spesifik dalam pembelajaran.
Technological Pedagogical Knowledge (TPK) Technological Pedagogical Knowledge (TPK) adalah pengetahuan tentang bagaimana berbagai teknologi dapat digunakan dalam pengajaran, dan memahami bahwa menggunakan teknologi dapat mengubah cara guru mengajar (Schmidt \& Mishra, 2009). Dengan kata lain bahwa teknologi berpengaruh dalam proses pembelajaran (Abbitt, 2014). Hasil analisis data angket pada aspek Technological Pedagogical Knowledge dapat dilihat pada Tabel 7 berikut ini. 
Tabel 7. Hasil angket untuk aspek Technological Pedagogical Knowledge

\begin{tabular}{|c|l|c|c|c|}
\hline NO & \multicolumn{1}{|c|}{ PERNYATAAN } & SKOR & SD & KATEGORI \\
\hline 1 & $\begin{array}{l}\text { Mengunakan aplikasi komputer dalam setiap mengajar } \\
\text { biologi }\end{array}$ & 3.28 & 0.93 & Cukup \\
\hline 2 & $\begin{array}{l}\text { Dapat memilih teknologi yang sesuai dengan pendekatan } \\
\text { dan strategi belajar yang dilaksanakan di kelas }\end{array}$ & 3.58 & 0.75 & Baik \\
\hline 3 & $\begin{array}{l}\text { Menggunakan fasilitas internet seperti media sosial, email, } \\
\text { blog untuk berkomunikasi dengan siswa }\end{array}$ & 3.76 & 0.77 & Baik \\
\hline 4 & $\begin{array}{l}\text { Melakukan kuis secara on line seperti menggunakan } \\
\text { socrative, edmodo, quiper school }\end{array}$ & 2.90 & 0.89 & Cukup \\
\hline 5 & $\begin{array}{l}\text { Dapat memfasilitasi siswa saya menggunakan teknologi } \\
\text { untuk menemukan lebih banyak informasi secara mandiri }\end{array}$ & 3.40 & 0.76 & Baik \\
\hline 6 & $\begin{array}{l}\text { Dapat memfasilitasi siswa saya menggunakan teknologi } \\
\text { untuk merencanakan dan memantau pembelajaran mereka } \\
\text { sendiri. }\end{array}$ & 3.36 & 0.88 & Cukup \\
\hline 7 & $\begin{array}{l}\text { Dapat memfasilitasi siswa saya menggunakan teknologi } \\
\text { untuk membangun berbagai bentuk representasi } \\
\text { pengetahuan }\end{array}$ & 3.31 & 0.85 & Cukup \\
\hline & RATA-RATA & 3.37 & 0.83 & Cukup \\
\hline
\end{tabular}

Data yang terdapat pada Tabel 7 menunjukkan bahwa Technological Pedagogical Knowledge calon guru biologi memiliki nilai rerata 3.37 yang berada pada kategori cukup. Dibadingkan dengan aspek TPACK yang lain aspek Technological Pedagogical Knowledge tidak sampai pada kategori baik. Hal ini dimungkinkan karena aspek Technological Pedagogical Knowledge membutuhkan sarana teknologi di suatu lembaga pendidikan, sehingga jika kelengkapan teknologi tidak difasilitasi maka penggunaan teknologi menjadi terbatas dalam proses pembelajaran. Saat mereka memilih metode/model pembelajaran mereka memilih metode/model pembelajaran yang sedikit menggunakan teknologi, walaupun pengetahuan mereka tentang teknogi tinggi, tetapi kesulitan menyatukannya dengan komponen pedagogi yang digunakan.

Technological Pedagogical Content Knowledge (TPCK)

Technological Pedagogical Content Knowledge (TPCK) merupakan pengetahuan tentang megintegrasikan teknologi ke dalam pembelajaran pada konten tertentu atau spesifik (konten biologi) yang (Schmidt \& Mishra, 2009; Kohler et all, 2014 ). Hasil analisis data angket pada aspek Technological Pedagogical Content Knowledge dapat dilihat pada Tabel 8 berikut ini. 
Tabel 8. Hasil angket untuk aspek Technological Pedagogical Content Knowledge

\begin{tabular}{|c|c|c|c|c|}
\hline NO & PERNYATAAN & SKOR & SD & KATEGORI \\
\hline 1 & $\begin{array}{l}\text { Dapat memilih strategi pembelajaran dan teknologi yang } \\
\text { sesuai dengan materi biologi yang akan disampaikan pada } \\
\text { kegiatan pembelajaran di kelas }\end{array}$ & 3.63 & 0.7 & Baik \\
\hline 2 & $\begin{array}{l}\text { Dapat memahami bagaimana memadukan pengetahuan } \\
\text { biologi, pengetahuan pedagogik, dan pengetahuan teknologi } \\
\text { yang saya miliki untuk mewujudkan pembelajaran biologi } \\
\text { yang bermakna }\end{array}$ & 3.56 & 0.64 & Baik \\
\hline 3 & $\begin{array}{l}\text { Dapat menerapkan berbagai macam strategi belajar dan } \\
\text { berbagai macam teknologi dalam melaksanakan } \\
\text { pembelajaran biologi }\end{array}$ & 3.54 & 0.69 & Baik \\
\hline 4 & $\begin{array}{l}\text { Dapat membantu kolega saya dalam memahami cara } \\
\text { memadukan pengetahuan biologi, pengetahuan pedagogi, } \\
\text { dan pengetahuan teknologi. }\end{array}$ & 3.35 & 0.61 & Cukup \\
\hline \multicolumn{2}{|r|}{ Rata-rata } & 3.52 & 0.66 & Baik \\
\hline
\end{tabular}

Berdasarkan data yang terdapat pada Tabel 7 di atas terungkap bahwa nilai rararata aspek Pedagogical Content Knowledge calon guru biologi berada dalam ketegori baik $(M=3.52)$. Hal ini dapat dimaknai bahwa calon guru biologi telah dapat memamahi bagaimana mengintegrasi pengetahuan teknologi, pedagogi dan konten/materi dalam pembelajran di kelas.

\section{KESIMPULAN}

Kemampuan untuk mengintegrasikan pengetahuan teknologi, pedagogi dan konten/materi biiologi (Tecnological pedagogical and content knowledge) penting untuk dimiliki oleh calon guru biologi. Hasil penelitian ini menunjukkan bahwa kemampuan (Tecnological pedagogical and content knowledge)calon guru biologi program studi pendidikan biologi fakulas tarbiyah dan keguruan UIN SGD Bandung berada dalam kategori baik. Hal ini dapat dimaknai bahwa calon guru biologi telah dapat menyelenggarakan pembelajaran biologi dengan pengintegrasikan teknologi informasi dan komputer.

\section{UCAPAN TERIMA KASIH}

Ucapkan terima kasih disampaikan kepada Lembaga Penelitian UIN Sunan Gunung Djati Bandung yang telah mendanai kegiatan penelitian ini.

\section{DAFTAR PUSTAKA}

Abbitt, J.T. (2014). An Investigation of the Relationship between Self-Efficacy Beliefs about Technology Integration and Technological Pedagogical Content Knowledge (TPACK) among Preservice Teachers. Journal of Digital Learning in Teacher Education 27 ( 4), 134- 143.

Alayyar, G., Fisser, P., \& Voogt, J. (2012). Developing Technological Pedagogical Content Knowledge in pre-service science teachers: Support from blended learning. Australasian journal of educational technology, 28(8), 12981316.

Andrea, B. Gabriella, H.C. and Tímea, J. (2016). $\mathrm{Y}$ and $\mathrm{Z}$ Generations at Workplaces. Journal of Competitiveness 8: (3), 90 - 106. 
APJII (asosiasi penyelenggara jasa internet indonesia) (2016). Saatnya jadi Pokok Perhatian Pemerintah dan Industri. Buletin APJII edisi 5.

Behrstock, E. and Cifford, M. (2009). Leading Gen Y Teachers: Emerging Strategy for Schol Leader. National Comprehensive Center for Quality Teacher: Washington DC.

Chai C.S, Koh, Tsai, \& Tan (2011). Modeling primary school pre-service teachers'Technological Pedagogical Content Knowledge (TPACK). Computers \& Education, 57(2011), 1184-1193.

Chai, C.S., Koh, J. H.L., \& Tsai, C.C. (2013). A Review of Technological Pedagogical Content Knowledge. Educational Technology \& Society, 16 (2), 31-51.

De Rossi, M. and Trevisan, O. (2018). Technological Pedagogical Content Knowledge in the literature: how TPCK is defined and implemented in initial teacher education. Italian Journal of Educational Technology, 26 (1), $8-23$.

Hewitt, J. (2008). Reviewing the handbook of technological pedagogical content knowledge (TPCK) for educators. Canadian Journal of Science, Mathematics, and Technology Education, 8(4), 355-360.

Hunt, J.E and Tucciorane, J. (2011). The challenges and Opportunities of Teaching "Generation Y" Journal of Graduate Medical Education 458 -461.

Kohler, M.J. Mishra, P. Kereluik, K. Shin, T.S. and Graham, C.R. (2014). The Technological Pedagogical Content Knowledge Framework dalam Handbook of Research on Educational Communications and Technology. New york: Springer Science+Business Media.
Koehler, M. J., \& Mishra, P. (2009). What is technological pedagogical content knowledge? Contemporary Issues in Technology and Teacher Education, 9(1), 60-70.

Loughran, J., Berry, A., \& Mulhall, P., (2012), Understanding and developing science teacher's pedagogical content knowledge, Rotterdam: Sense Publishers.

Mishra, P. dan M. J. Koehler. (2006). Technological Pedagogical Content Knowledge: A Framework for Teacher Knowledge. Teachers College Record. 6 (108): 1017-1054.

National Research Concil. (1996). National Science Education Standards. Washington DC: National Academy Press.

Neville, T. (2005). Postlethwaite Educational research: some basic concepts and terminology. International Institute for Educational Planning/UNESCO, p 9.

NSTA (2012). Standards for science teacher preparation. National Science Teachers Association in collaboration with the association for the Education of Teachers in Science.

Oyanagi, W. and Satake, Y. (2016). Capacity Building in Technological Pedagogical Content Knowledge for Preservice Teacher. International Journal for Educational Media and Technology, 10 (1), 33 - 44.

Schmidt, D. A., Baran, E., Thompson, A. D., Mishra, P., Koehler, M. J., \& Shin, T. S. (2009). Technological Pedagogical Content Knowledge (TPACK): The development and validation of an assessment instrument for pre-service Teachers. Journal of Research on Technology in Education, 42(2), 123-149. 
Shulman, L. S. (1986). Those Who Understand: Knowledge Growth in Teaching. Educational Researcher, 15 (2), 4-14.

Shulman, L. (1987). Knowledge and teaching: foundations of the new reform. Harvard Educational Review, 57(1), 1-22.

Srisaswadi. N. (2012). The Role of TPACK in Physics Classroom: Case Study of Preservice Physics Teachers. Procedia Social and Behavioral Sciences, 46, 3235 - 3234.

Suryawati, E., Hernandez, Y. Firdaus L.N. (2014). Analisis Keterampilan Technological Pedagogical Content Knowledge (TPCK) Guru Biologi SMA Negeri Kota Pekanbaru. Jurnal Biogenesis. 11 (1), 67-72.

Tian, Evi, \& Hussien. (2012). Technological Pedagogical Profile Content Knowledge (TPCK) Prospective Students FKIP Biology Teacher University Of Riau. Bio-Edu, 1-12.

Undang-undang Nomor 14 tahun 2005 tentang guru dan dosen

White, G. and Kiegaldie, D. (2011). Gen Y learners: just how concerned should we be? The Clinical Teacher 8: 263-266. 